\title{
PERCUTANEOUS ENDOSCOPIC LUMBAR INTERBODY FUSION: RESULTS OVER 47 MONTHS OF FOLLOW-UP
}

\section{ARTRODESE LOMBAR INTERSOMÁTICA ENDOSCÓPICA PERCUTÂNEA: RESULTADOS DEPOIS DE 47 MESES DE ACOMPANHAMENTO}

\author{
anibal Correia Silva ${ }^{1,2}$ (1) , Tabata de Alcantara ${ }^{1}$ [1], Monica Paschoal nogueira, ${ }^{2,3}$ (1) \\ 1. Universidade Potiguar, Medical School, Department of Orthopedics, Natal, RN, Brazil. \\ 2. Instituto de Assistência Médica ao Servidor Público Estadual (IAMSPE), Postgraduate Program, São Paulo, SP, Brazil. \\ 3. Hospital do Servidor Público Estadual de São Paulo (HSPE), Orthopedics and Traumatology Department, São Paulo, SP, Brazil.
}

\section{ABSTRACT}

Introduction: This study aims to investigate the clinical-functional results of a new surgical technique, Percutaneous Endoscopic Lumbar Interbody Fusion (PELIF), in patients with a clinical diagnosis of low back or sciatic pain and segmental instability who were submitted to surgery using this technique assisted by the attending physician. Materials and methods: Patients completed a consent form and were clinically and radiographically re-assessed by independent evaluators using the visual analog scale (VAS) for pain, the Oswestry Disability Index (ODI), and the SF-36 Quality of Life Score in the pre- and postoperative periods. Their medical records were also reviewed for surgical time, length of hospital stay, need for blood transfusion, return to work, and radiographic fusion evaluation. Results: In the group of 19 patients with 33 levels operated, VAS and ODI decreased from 10.0 and $64 \%$ to 2.0 and $28 \%$, respectively. The SF-36 showed significantly higher scores in 5 of its 7 domains at the end of the follow-up as compared to the preoperative period scores. Only 1 case of pseudoarthrosis was diagnosed radiographically. Conclusions: Percutaneous Endoscopic Lumbar Interbody Fusion (PELIF) has been shown to be a safe and efficient technique for the treatment of patients with segmental instability associated with low back or sciatic pain. Level of Evidence VI; Therapeutic Study; Case Series.

Keywords: Spine/surgery. Arthrodesis. Endoscopy.

\section{RESUMO}

Introdução: Este estudo tem como objetivo investigar os resultados clínico-funcionais de uma nova técnica cirúrgica, artrodese lombar endoscópica percutânea (PELIF) em pacientes com diagnóstico clínico de dor lombar ou ciática e instabilidade segmentar, submetidos à referida técnica pelo médico responsável. Materiais e métodos: Os pacientes preencheram um termo de consentimento livre e esclarecido e foram reavaliados clínica e radiograficamente por avaliadores independentes que usaram a Escala Visual Analógica (EVA) para dor, Índice de Incapacidade de Oswestry (ODI) e o Short Form Health Questionnaire SF-36 nos períodos pré e pós-operatório. Foram também pesquisados nos prontuários médicos tempo de cirurgia, tempo de internação hospitalar, necessidade de transfusão de sangue, retorno ao trabalho e avaliação radiográfica da fusão. Resultados: Na amostra final de 19 pacientes com 33 níveis operados, EVA e ODI diminuíram de 10,0\% e 64\% para 2,0\% e $28 \%$, respectivamente. O SF-36 mostrou escores significativamente maiores em 5 de seus 7 domínios no final do acompanhamento, em comparação com o período pré-operatório. Somente 1 caso de pseudoartrose foi diagnosticado por radiografia. Conclusões: $A$ artrodese lombar endoscópica percutânea (PELIF) tem se mostrado uma técnica segura e eficiente para o tratamento dos pacientes com instabilidade segmentar associada a lombalgia ou ciatalgia. Nível de Evidência IV; Estudos Terapêuticos; Série de Casos.

Descritores: Coluna vertebral/cirurgia. Artrodese. Endoscopia.

Citation: Silva AC, T Alcantara T, Nogueira MP. Percutaneous endoscopic lumbar interbody fusion: results over 47 months of follow-up. Randomized Trial. Acta Ortop Bras. [online]. 2022;30(1): Page 1 of 5. Available from URL: http://www.scielo.br/aob.

\section{INTRODUCTION}

Low back pain is a major cause of incapacity for work in the western world, with difficult resolution and ineffective responses. Modern techniques have provided better results, but with an increase in costs. ${ }^{1}$ The first disc resection was done by Mixter \& Barr, in 1934. ${ }^{2}$ Using an arthroscope, Hijikata et al., ${ }^{3}$ achieved intervertebral disc resection, being enhanced by Kambin \& Gellman ${ }^{4}$, with the description of "Safety Triangle", between the exiting and descending roots, the basis of foraminal accesses. ${ }^{5}$ The introduction of pedicular screws, associated with transforaminal lumbar interbody fusion (TLIF), ${ }^{6}$ with less dissection and neural retraction, a well-established surgical technique for many vertebral lesions. ${ }^{7}$ Fusion is the "gold standard" in the invasive treatment of low back pain and can be achieved by different approaches, however, they are invasive, with blood loss, muscle damage and resections many structures, generating the so-called "fusion disease". ${ }^{8}$

All authors declare no potential conflict of interest related to this article.

The study was conducted at the Hospital do Servidor Público Estadual de São Paulo (HSPE), São Paulo, SP, Brazil.

Correspondence: 1140 Ceará Mirim St., Natal, RN, Brazil. 59020-240. anibalcoluna@yahoo.com.br 
These comorbidities, such as epidural fibrosis, leading to the search for minimally invasive techniques, such as MIS-TLIF. ${ }^{8}$

Modern endoscopes have avoids these approaches'complications, allowing views of disc space and spinal canal, direct neural structure'access and showing evidence compared with established techniques. ${ }^{9}$

The advent of percutaneous fixation and tubular dilators, for less aggressive fusion showed, however, some limitations. ${ }^{10}$ But, the video decompression, associated with percutaneous fixation, provided the Percutaneous Endoscopic Lumbar Interbody Fusion (PELIF), ${ }^{11}$ with the same classical surgery objectives, but lower morbidity. However, would the surgical results be the same? This study investigates whether the PELIF technique achieves the same objectives as conventional arthrodesis, and with good clinical-functional results.

\section{MATERIALS AND METHODS}

The inclusion criteria were chronic low back or sciatic pain, with segmental instability (vertebral translation of 3.0 to $3.5 \mathrm{~mm}$, or intervertebral angulation greater than $10^{\circ}$ on dynamic radiographs), resultant in pain or neurologic symptoms ${ }^{12}$ and unresponsive to effective clinical treatment for at least 06 (six) weeks, presenting the classic indications for conventional fusion but underwent PELIF.

\section{Study group}

They were attended, by the author, from April 2009 to July 2015, and the diagnosed of tumor, infection, previous surgery and those undergoing PELIF but re-operated in other services were excluded. Patients were clinically and radiologically assessed by independent evaluators using the Visual Analogue Scale (VAS) of pain, ${ }^{13}$ Oswestry Disability Index (ODI) ${ }^{14}$ and SF-36 Quality of Life Score, ${ }^{15}$ on pre- and postoperative period. Surgical data (surgery time, length of hospital stay, need for blood transfusion) and demographics were obtained from medical charts. Radiographic fusion was confirmed by computed tomography (CT) showing bone trabeculae between vertebral bodies. ${ }^{8}$ The patients were informed about the objectives of the study and signed the written informed consent form. This study was approved by the Ethics Committee (protocol number 2.546.754).

\section{Surgical technique}

The PELIF, described by Morgenstern, ${ }^{11}$ uses percutaneous access through a sequential tube system and direct visualization by the endoscope.

The preoperative images show the interest area and the entry point puncture, avoiding neural manipulation. The general anaesthesia, in prone position, with puncture by $18 \mathrm{G}$ needle guided and image enhancer, accessing the disc through transforaminal approach. Discography is performed with iodinated contrast and dye, followed by the placement of a guidewire in the disc center. (Figure 1)

The needle is removed, with dilators passing over the guidewire, ending with a working cannula and dilators removal, followed by endoscopic optics ( $4.1 \mathrm{~mm}$ working channel) entrance. Visualization of the disc space and adjacent neural structures. Haemostasis is performed by radiofrequency probe. The superior articular process is partially resected by drill, with foraminal enlargement (Figure 2) and avoiding postoperative instability or perineural fibrosis. This allow the entry of 04 (four) new larger diameter tubular dilators, with the latter having a working channel of $15.5 \mathrm{~mm}$.

The simultaneous endoscopic and radioscopic guidance, avoiding neural interposition and enabling passage to disc reamers and curettes with larger diameter, to faster and more efficient material removal and debridement of the vertebral end plate. (Figure 3) After this, the anterior intersomatic space is filled with 10 grams of heterologous bone graft (hydroxyapatite) and, with previous measurement tests, we introduced the polyetheretherketone (PEEK) intersomatic CAGES. Two CAGES are placed according to each patient's biotype, parallels and in the anterior third of the intersomatic space. The $15 \mathrm{~mm}$ cannula allows direct CAGES and bone graft visualization in the intersomatic space. (Figure 4) The Spinal fixation is followed by the use of a percutaneous pedicle screw system. ${ }^{16}$

\section{Statistical Analysis}

The collected data were submitted to statistical analysis, with categorical data in absolute (n) and relative (\%) values and continuous data verified by the Shapiro-Wilk test. Variables with normal distribution were described as mean and standard deviation and those without normal distribution were described as medians and quartiles 25 and 75. The student $t$ test was used to compare variables with normal distribution and Wilcoxon rank test to compare variables without distribution. We compared pain perception at three stages of the study evaluation (before, one week and three years after surgery)

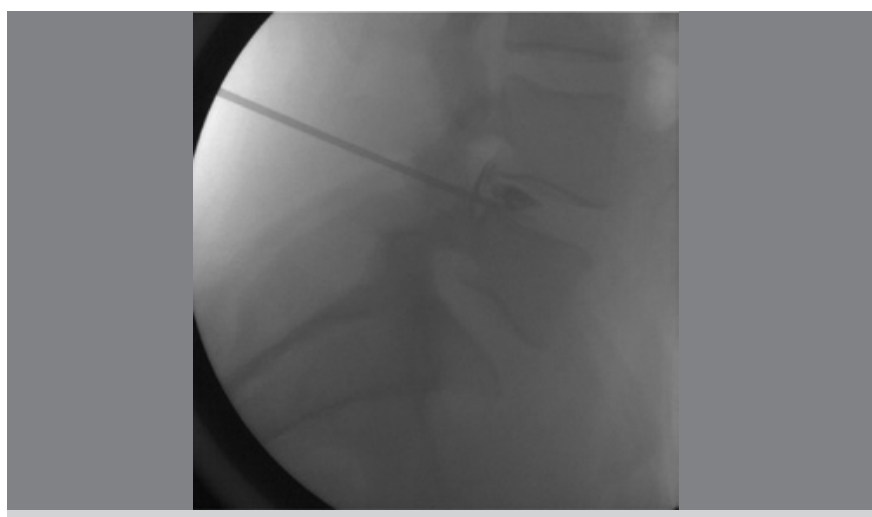

Figure 1. Discography with guidewire placement in the center of the disc.

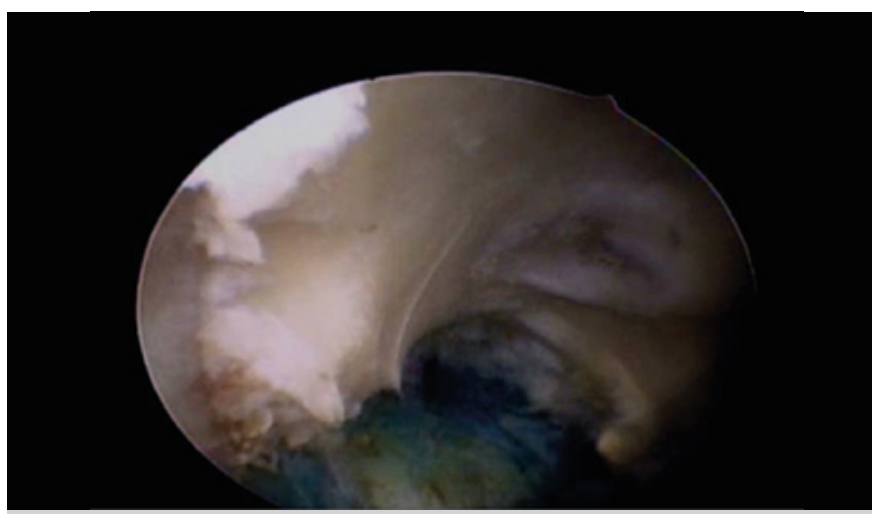

Figure 2. Superior facet partially resected by endoscopic drill.

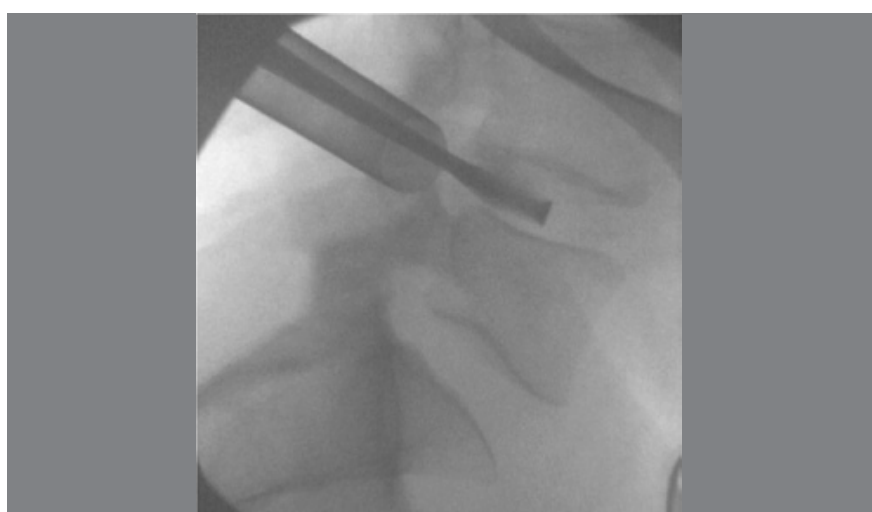

Figure 3. $15.5 \mathrm{~mm}$ working channel, with a series of larger diameter reamers and curettes for debridement of the vertebral end plate. 
with the Friedman test and the binary correlation between continuous variables made by Spearman's product-moment coefficient. The statistical significance level used for all analyzes was $p<0.05$, using the 25.0 SPSS version statistical package (IBM ${ }^{\circ}$, Chicago, IL, USA).

\section{RESULTS}

For an initial sample of 24 patients, we had 05 losses (04 reoperations in other services and one death from urban violence), leaving 19 patients, 17 men and 02 women, with a mean age of $36.1 \pm$ 1.2 years. The mean follow-up time was 47.0 (29.0 - 70.0) months. Thirty-three levels were operated, with $73.7 \%$ of cases operating two levels, always between L2 and S1. CAGES of $08 \mathrm{~mm}$ and 10 $\mathrm{mm}$ were used, according to pre-introduction tests.

The mean surgical time was 355.0 (275.0 - 420.00) minutes, with patients hospital discharged in $3.0(2.0$ - 4.0) days. The mean blood loss was $215.8 \pm 76.5 \mathrm{ml}$ and there was no blood transfusion. Among the 19 patients, only one had lower back pain after surgery and 11 had leg pain. Return to work after surgery was $31.6 \%$.

The patients' results related to the surgical procedure and epidemiological data are presented in Table 1.

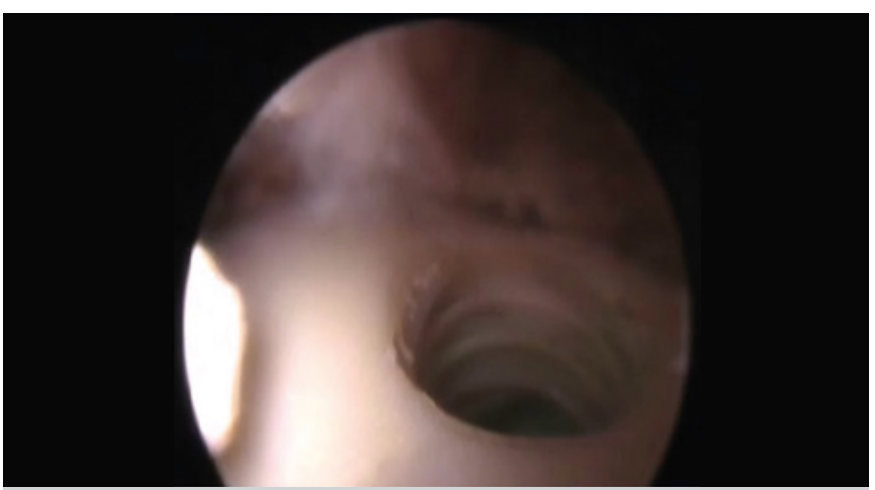

Figure 4. Final endoscopic cage view between vertebral plateaus.

Table 1. Surgical procedure characteristics and patients clinical status before and after surgery. $(n=19)$.

\begin{tabular}{|c|c|c|}
\hline Characteristic & n (\%) & $\begin{array}{c}\text { Mean SD or } \\
\text { Mean (Q25 and Q75) }\end{array}$ \\
\hline \multicolumn{3}{|l|}{ Operated level } \\
\hline 1 & $5(26.3)$ & - \\
\hline 2 & $14(73.7)$ & - \\
\hline \multicolumn{3}{|l|}{ Operated side } \\
\hline Right & $10(52.6)$ & - \\
\hline Left & $9(47.4)$ & - \\
\hline Surgery duration (min) & - & $355.0(275.0-420.00)$ \\
\hline Hemoglobin concentration before $(\mathrm{g} / \mathrm{dl})$ & - & $15.2 \pm 1.1$ \\
\hline Hematocrit concentration before (\%) & - & $45.2 \pm 2.6$ \\
\hline Hemoglobin concentration after ( $\mathrm{g} / \mathrm{dl})$ & - & $11.4 \pm 1.8$ \\
\hline Hematocrit concentration after (\%) & - & $34.5 \pm 4.0$ \\
\hline Total Bleeding $(\mathrm{mL})$ & - & $215.8 \pm 76.5$ \\
\hline Length of hospital stay (days) & - & $3.0(2.0-4.0)$ \\
\hline Postoperative pain perception (u.a.) & - & $1.0(0.0-3.0)$ \\
\hline \multicolumn{3}{|l|}{ Post-surgery pain site } \\
\hline Free from pain & $7(36.8)$ & - \\
\hline Lumbar & $1(5.3)$ & - \\
\hline Leg & $11(57.9)$ & - \\
\hline \multicolumn{3}{|l|}{ Return to work } \\
\hline Not & $13(68.4)$ & - \\
\hline Yes & $6(31.6)$ & - \\
\hline
\end{tabular}

The median pain intensity before surgery was 10.0 (9.0 - 10.0) u.a. on VAS, decreasing to $1.0(0.0$ - 3.0) u.a. on postoperative. There was no statistically significant difference in pain intensity between one week $1.0(0.0$ - 3.0) u.a. and at the end of follow-up $2.0(0.0$ - 4.0) $\left[{ }^{x 2}(2)=29.288, p<0.001\right]$. (Figure 5)

Control MRIs showed preservation of the paravertebral muscles, eliminating the high rate of fat replacement, showing that transforaminal percutaneous access reduces soft tissue lesions. (Figure 6) Comparison of Owestry score functionality showed decrease before surgery and at the end of follow-up [64.0 (52.0 to 70.0) vs. 28.0 (20.0 to 36.0$) \% ; z=-3.503, p<0.001]$. (Figure 7 )

Comparison of quality of life by SF-36, preoperative and at the end of follow-up, showed improvement in functional capacity scores $(z=-3.509 ; p<0.001)$, physical aspects limitations $(z=3.535$; $p<0.001)$, pain $(z=3.624$; $p<0.001)$, general SF-36 status $(z=3.333 ; p=0.001)$ and vitality $(z=3.247 ; p=0.001)$. The social aspects $(z=-0,700 ; p=0,484)$ and mental health $(z=-1,479$; $p=0,139)$ domains were similar before surgery and at the end of follow-up. (Table 2)

We had four complications with reinterventions: a cage migration, a subsidence with cage removal, an infection and a medially positioned screw. None of the cases required conversion to open surgery, with all complications being corrected by the same technique and only 01 of 19 patients had pseudarthrosis.

\section{DISCUSSION}

The surgical lombar procedures show good results in the longterm. However, the postoperative period has limitations like pain, instability and epidural fibrosis. ${ }^{1}$

We had five losses in 19 patients. Jacquot and Gastambide, ${ }^{17}$ reported 32 losses in 57 endoscopic fusions. The follow-up time

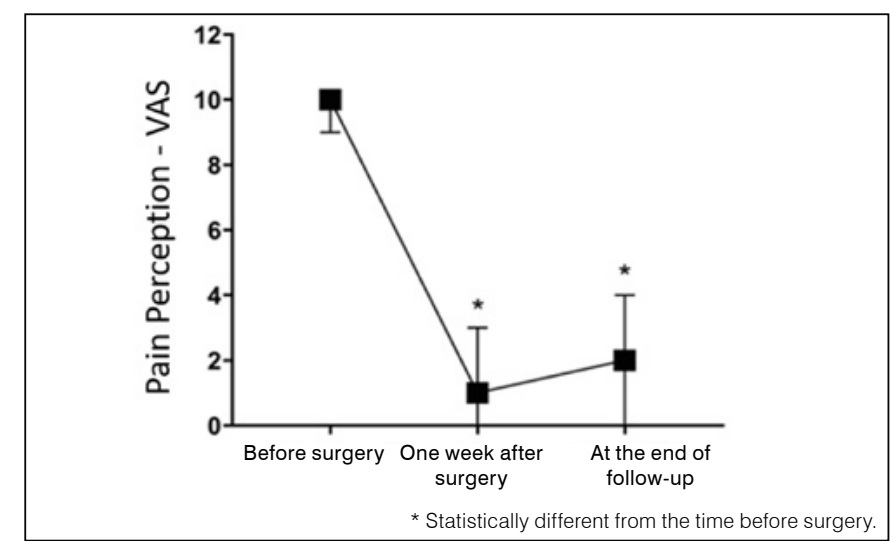

Figure 5. Perception of pain before, one week after surgery and at the end of follow-up ( $n=19)$. Data expressed as median and quartiles 25 and 75 .

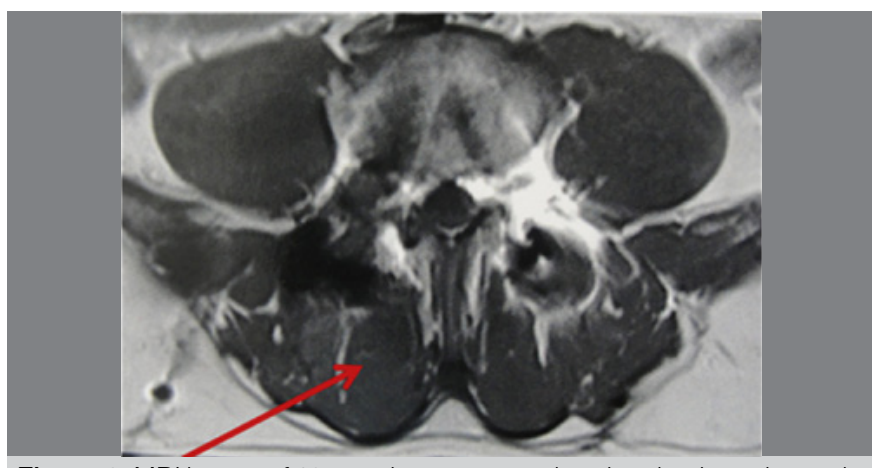

Figure 6. MRI image of 12 months postoperative showing broad muscle preservation (see arrow). 


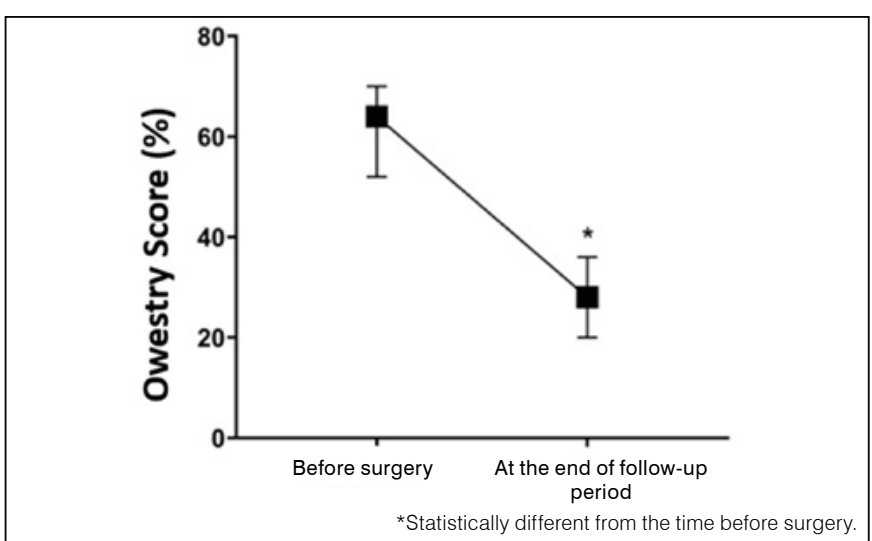

Figure 7. Oswestry score functionality before surgery and at the end of follow-up. Data expressed as medians and quartiles 25 and 75

Table 2. Quality of life by SF-36 before surgery and at the end of follow-up
$(\mathrm{n}=19)$.
\begin{tabular}{c|c|c|c}
\hline SF-36 Domain & Before & At the end of follow-up & p-value \\
\hline Physical capacity & $10(0-25)$ & $90(50-100)$ & $<0.001$ \\
\hline Physical aspects limitations & $0(0-0)$ & $100(25-100)$ & $<0.001$ \\
\hline Pain & $0(12-22)$ & $62(51-100)$ & $<0.001$ \\
\hline General health status & $25(5-35)$ & $82(57-100)$ & 0.001 \\
\hline Vitality & $25(10-40)$ & $80(50-100)$ & 0.001 \\
\hline
\end{tabular}

Data expressed as mean \pm standard deviation or median and (quartiles 25 - 75). P-value in bold equals statistically significant differences.

was 47.0 (70.0 - 29.0) months. Lee et al. ${ }^{18}$ had 46 (12-123) months of follow-up time.

The limitations in the CAGES introduction were clear, with 12 patients received $08 \mathrm{~mm}$ size CAGES and just 07 received $10 \mathrm{~mm}$ CAGES, in a total of 19 cases, according to the tests used. Jacquot and Gastambide $^{17}$ had similar difficulty, even using bilateral pathways, inserting only one cage in three of 57 patients. The expandable CAGES did not solve the problem, with five broke implants, one reintervention by implant migration and 02 pseudarthrosis in 18 patients.

Lee et al..$^{18}$ did not use posterior fixation and, with a sample similar to ours (18 patients), had twice as much pseudarthrosis (02 cases). The expandable CAGES provided postoperative dysesthesias too, with 14 cases in 24 patients, and "minimal subsidence" in 7 cases, with significant subsidence in two, both requiring reintervention. ${ }^{1}$ We had one subsidence, being corrected by the PELIF technique itself. Other publications with both CAGES'models, found no differences between the two groups, suggesting that the type of cage does not interfere with the final outcome. ${ }^{11}$

Our mean surgical time was 355.0 (275.0 - 420.00) minutes. Wang and Grossman ${ }^{(5)}$ had a mean operative time of $113.5 \pm 6.3$ minutes (range 105 to 120 minutes), showing an initial learning curve, but with a hospital discharge in $3.0(2.0$ - 4.0) days, compared to the same study which had a discharge time of $1.4 \pm 1,3$ nights, ${ }^{5}$ showing that the surgery time did not affect the patients' postoperative.

The blood loss was $215.8 \pm 76.5 \mathrm{ml}$, similar to others with $238 \mathrm{~mL}$ $(140-350)^{16}$ and there was no blood transfusion.

We had only one postoperative lombar pain in 19 patients. The PELIF uses successive dilators, with minimal incisions and few soft tissue lesions (Figure 6), reducing postoperative pain and long-term complications ${ }^{19}$ Our final working cannula $(15.5 \mathrm{~mm})$ (Figure 3), is similar to others with a $12 \mathrm{~mm}^{11}$ and compatible with anatomical studies showing an average size of $15.5 \mathrm{~mm}$ at the working triangle because, other authors, have found an average from 18.5 to $26.6 \mathrm{~mm} .{ }^{5}$ These limits are more than sufficient for the access of our dilators $(15.5 \mathrm{~mm})$.
Transforaminal endoscopic access prevents scar tissue, epidural adhesions and reduces soft tissue lesions, eliminating fat paravertebral muscles replacement ${ }^{18}$ similar to found in our PELIF. (Figure 6) However, we had 11 leg pain patients in the immediate postoperative period (Table 1) and, although transitory and low-intensity (u.a.): $1.0(0.0-3.0)$, is similar to others, and considered as "inevitable". 9 The final $15.5 \mathrm{~mm}$ working fusion cannula, when compared to traditional endoscope, increases postoperative dysesthesia, but provides direct neural visualization in CAGE introduction.

There was improvement in all clinical parameters (VAS, Oswestry Scale and SF-36) on postoperative, when we compare them before, one week after surgery and at the end of follow-up time, showing an immediate pain improvement and mainly, same after three years of follow-up, remaining with low scores. (Figure 5) The good results in minimally invasive procedures, especially in VAS measurement, is widely demonstrated in the literature. ${ }^{1}$

The Owestry score was lower at the end of follow-up compared to the time before surgery [64.0 (52.0 to 70.0) vs. 28.0 (20.0 to 36.0) \%; $z=-3.503, p<0.001$ ], with an improvement over $100 \%$. Other studies have shown average scores from $69.9 \pm 14.3$ (range, $44.4-92$ ) to $22.3 \pm 17.1$ (range, 4-71.1) with $69 \%$ improvement $(\mathrm{p}<0.001)(18)$.

The SF-36 data are useful for assessing patients' overall health status. ${ }^{15}$ Our findings showed the domains functional capacity $(z=-3.509 ; p<0.001)$, physical aspects limitation $(z=3.535$; $p<0.001)$, pain $(z=3.624 ; p<0.001)$, general health status $(z=3.333 ; P=0.001)$ and vitality $(z=3.247 ; p=0.001)$ were higher at the end of follow-up compared to preoperative period, with $p$-values showing a statistically significant difference, especially in the limitation and pain domains.

Our fusion rate was high, with only one patient presenting pseudarthrosis, verified by computed tomography with the presence of bone trabeculae between vertebral bodies. This patient was also the only one who, due to subsidence, had his CAGES removed and, because of the lesion on the upper vertebral plateau, we could not place a new device.

Other authors found a low subsidence rate of PEEK-like CAGES too, because the access route and surgical aggression in this technique are very small. They correlated the subsidence at the L5-S1 level and the anterior cage positioning. ${ }^{19,20}$ Our case (level L4-L5), coincided only the anterior position of the cage.

Our complications are similar to literature, ${ }^{18}$ with only four cases requiring reintervention. One cage migration, one subsidence, one case of infection, and one medially positioned screw. The authors Jacquot and Gastambide ${ }^{17}$ had 13 of 57 patients with CAGES migration (22.8\%), requiring conventional reoperations, because just eleven had a simultaneous posterior fixation at the first procedure, which may be the cause of high rate cage migration. In our sample, no patient required conversion to open surgery, with all complications being corrected by PELIF, including the only case with cage migration.

These found, similar to others, ${ }^{18}$ the percutaneous endoscopic lumbar interbody fusion (PELIF) has achieved the expected goal (fusion) and is a safe and effective option for minimally invasive neural decompression.

This is an original technique and although it presents results comparable to similar others, ${ }^{1,11,16,18}$ it has particularities that differ substantially from them.

\section{CONCLUSION}

The present study provides evidence that Percutaneous Endoscopic Lumbar Interbody Fusion (PELIF) is a safe option for interbody fusion and patients have good clinical-functional outcomes with a minimum of 29 months of follow-up. 
AUTHORS' CONTRIBUTION: Each author made significant individual contributions to this manuscript. ACS: Conceptualization, Writing - Original Draft. TA Methodology, Investigation, Resources, Writing - Review \& Editing. MPN: Methodology, Validation, Formal analysis, Writing - Review \& Editing, Supervision.

\section{REFERENCES}

1. Lewandrowski KU. Surgical technique of endoscopic transforaminal decompression and fusion with a threaded expandable interbody fusion cage and a report of 24 cases. J Spine. 2018; 7(2):1-8.

2. Mixter WJ, Barr JS. Rupture of the intervertebral disc with involvement of the spinal canal. N Engl J Med. 1934; 211(5):210-5.

3. Hijikata S, Yamagishi M, Nakayama T, Oomori K. Percutaneous discectomy: a new treatment method for lumbar disc herniation. J Toden Hosp. 1975;5:39-44.

4. Kambin P, Gellman H. Percutaneous lateral discectomy of the lumbar spine. A preliminary report. Clin Orthop. 1983;(174):127-32.

5. Wang MY, Grossman J. Endoscopic minimally invasive transforaminal interbody fusion without general anesthesia: initial clinical experience with 1-year follow-up. Neurosurg Focus. 2016;40(2):E13.

6. Harms JG, Jeszenszky D. Die posteriore, lumbale, interkorporelle fusion in unilateraler transforaminaler technik. Oper Orthop Traumatol. 1998;10(2):90-102.

7. Avanzi O, Chih LY, Meves RS, et al. Spinal osteoblastoma: 27 years of experience. Rev Bras Ortop. 2004;39(4):147-54.

8. Menezes CM, Falcon RS, Ferreira Júnior MA, Alencar J. Clinical and radiological evaluation of open transforaminal lumbar interbody fusion versus minimally invasive. Coluna/columna. 2009;8(3):297-302.

9. Yeung AT, Tsou PM. Posterolateral endoscopic excision for lumbar disc herniation: Surgical technique, outcome, and complications in 307 consecutive cases. Spine (Phila Pa 1976). 2002;27(7):722-31.

10. Foley KT, Holly LT, Schwender JD. Minimally invasive lumbar fusion. Spine (Phila Pa 1976). 2003;28(15 Suppl):S26-35.

11. Morgenstern R. Full endoscopic transforaminal lumbar interbody fusion approach with percutaneous posterior transpedicular screw fixation in a case of spondylolisthesis grade I with L4-5 central stenosis. J Crit Spine Cases. 2010;3:115-9.

12. Panjabi MM. The stabilizing system of the spine. Part II. Neutral zone and instability hypothesis. J Spinal Disord. 1992;5(4):390-6.

13. Zanoli G, Strömqvist B, Jönsson B. Visual analog scales for interpretation of back and leg pain intensity in patients operated for degenerative lumbar spine disorders. Spine (Phila Pa 1976). 2001;26(21):2375-80.

14. Fairbank JC, Couper J, Davies JB, O'Brien JP. The Oswestry low back pain disability questionnaire. Physiotherapy. 1980;66(8):271-3.

15. Ware JE, Snow KK, kosinski M, Gandek BG, editors. SF-36 health survey: manual and interpretation guide. Boston, MA: The Health Institute, New England Medical Center; 1993.

16. Kim HS, Park KH, Ju Cl, Kim SW, Lee SM, Shin H. Minimally invasive multi-level posterior lumbar interbody fusion using a percutaneously inserted spinal fixation system: technical tips, surgical outcomes. J Korean Neurosurg Soc. 2011;50(5):441-5.

17. Jacquot F, Gastambide D. Percutaneous endoscopic transforaminal lumbar interbody fusion: is it worth it? Int Orthop. 2013;37(8):1507-10.

18. Lee SH, Erken HY, Bae J. Percutaneous transforaminal endoscopic lumbar interbody fusion: clinical and radiological results of mean 46-month follow-up. Biomed Res Int. 2017;2017:3731983.

19. Silva AC, Alcantara T, Nogueira MP. The percutaneous endoscopic lumbar interbody fusion (PELIF): an advanced and innovation technique. Int J Recent Surg Med Sci. 2019;5(1):31-4.

20. Kim MC, Chung HT, Cho JL, Kim DJ, Chung NS. Subsidence of polyetheretherketone cage after minimally invasive transforaminal lumbar interbody fusion. J Spinal Disord Tech. 2013;26(2):87-92. 